Teologia i Moralność, volumen 12(2017), numer 2(22)

doi: 10.14746/tim.2017.22.2.10

MARCIN DERDZIUK

Katolicki Uniwersytet Lubelski Jana Pawła II

Wydział Teologii

\title{
Praktyka eutanazji w Belgii jako owoc przemian społeczno-obyczajowych
}

Kongregacja Nauki i Wiary w deklaracji o eutanazji Iura et bona jednoznacznie potępia wszelkie zachowania eutanatyczne: „Nikomu nie wolno nastawać na życie człowieka niewinnego, ponieważ sprzeciwia się to miłości Boga wobec niego, narusza jego nieutracalne i niezbywalne, fundamentalne prawo i dlatego taki czyn jest bardzo ciężką zbrodnią"1. W kontekście tego zapisu warto przyjrzeć się uwarunkowaniom społeczno-obyczajowym kwestionowania prawa do życia przez ustawodawstwo Królestwa Belgii, gdzie 28 maja 2002 roku zalegalizowano eutanazję, a nowelizacja tej ustawy z 13 lutego 2014 roku umożliwia dokonywanie jej na osobach nieletnich, bez żadnych ograniczeń wiekowych. Celem niniejszego artykułu jest ukazanie dokonujących się działań eutanatycznych w Belgii jako konsekwencji rozpowszechnienia się permisywnego stylu życia, będącego owocem odejścia od Boga i utraty wiary. W świetle ukazanych faktów i wyjaśnienia ich przyczyn zostanie dokonana teologicznomoralna ocena zaprezentowanych zjawisk społecznych. Przyjmując twierdzenie, że największym niebezpieczeństwem dla społeczeństwa, które legalizuje eutanazję medyczną, jest utrata własnej duszy, w artykule zostanie podjęte zadanie ukazania wzajemnego powiązania tych rzeczywistości ${ }^{2}$. Warto zauważyć, że w Belgii, gdzie liczba wykonywanych eutanazji szybko rośnie, dostrzega się zjawisko polegające na zwiększaniu się liczby zamykanych kościołów. Przykładem tego może być diecezja Gandawa, która przygotowuje plan zamknięcia 15 parafii ${ }^{3}$.

\footnotetext{
${ }^{1}$ Kongregacja Nauki i Wiary, Deklaracja o eutanazji Iura et bona (05.05.1980), w: $W$ trosce o życie, Tarnów 1998 s. 334.

${ }^{2}$ Por. L. Israel, Eutanazja czy życie aż do końca, Kraków 2003, s. 132.

${ }^{3}$ Por. Belga, Tegen 2020 worden 15 Gentse parochiekerken gesloten, http://deredactie.be/cm/ vrtnieuws/regio/oostvlaanderen/1.2473812 [dostęp: 08.08.2016].
} 


\section{Zjawisko eutanazji w Belgii}

Wysoko rozwinięte kraje Beneluxu: Belgia, Holandia oraz Luksemburg, zalegalizowały eutanazję z różnych przyczyn. Chronologicznie rzecz ujmując, pierwszym państwem, który uchwalił ustawę uchylającą karalność eutanazji, była Holandia. Dokonał tego parlament 12 kwietnia 2001 roku. Ustawa weszła w życie 1 kwietnia 2002 roku. Od tego dnia Holandia stała się pierwszym krajem na świecie, „który materię zabójstwa eutanatycznego uregulował w specjalnie poświęconej ustawie o zakończeniu życia na żądanie i pomocnictwie w samobójstwie"4. Wśród krajów Beneluxu najbardziej wyróżniającym się, liberalnym i progresywnym w jej wykonywaniu, jest jednak Belgia. W roku 2007 odnotowano w tym kraju 1,9\%, a w roku 2013 4,6\% wszystkich zgonów, których przyczyną była „dobra śmierć” 5 . W ciągu ostatnich lat zabito tym sposobem ponad 15 tysięcy osób ${ }^{6}$.

Dopuszczenie eutanazji w Belgii w roku 2002 jest wynikiem bardzo skomplikowanego procesu, stanowiącego legalizację czynności, które i tak były praktykowane. Belgia należy do krajów, które zdystansowały się do encykliki Pawła VI Humane vitae (25.07.1968). Było to początkiem narastającego rozdźwięku pomiędzy Urzędem Nauczycielskim Kościoła a lokalnymi rozwiązaniami, pomiędzy prymatem papieża a kolegialnością biskupów wyżej wspomnianych krajów Beneluxu ${ }^{7}$. Nawet niektórzy teologowie belgijscy uważają, że Humanae vitae była atakiem na wolność oraz stała się proklamacją potęgi Rzymu. Spotyka się wypowiedzi, że kolegialność i współodpowiedzialność biskupów za Kościół zostały pogwałcone poprzez odgórnie narzucone nor$\mathrm{my}^{8}$. Bolesne jest to, że ci sami biskupi i teolodzy, którzy brali udział w opracowywaniu dokumentów II Soboru Watykańskiego (np. kard. L.J Suenens, bp G. Phipips, bp. J.M Heusschen, bp. A.M. Charue), odnieśli się bardzo krytycznie do Humanae vitae, publikując stosowny dokument (Reacties op de encycliek $^{9}$.

${ }^{4}$ Por. M. Szadkowska, Zabójstwo eutanatyczne -tendencje liberalizacyjne w Europie na przykladzie Belgii, „Studia Iuridica Toruniensia” https://repozytorium.umk.pl/bitstream/handle/ item/2023/SIT.2013.024,Szadkowska.pdf?sequence=1, s. 8 [dostęp: 08.08.2016].

${ }^{5}$ Por. K. Chambaere, R. Vander Stichele, F. Mortier, J.Cohen, L. Deliens, Recent Trends in Euthanasia and Other End-of-Life Practices in Belgium, "The New England Journal of Medicine" 2015. 372:1179-11. http://www.nejm.org/doi/full/10.1056/NEJMc1414527\#t=article. [dostęp: 08.08.2016].

${ }^{6}$ Por. Wet betreffende de euthanasie, http://www.ejustice.just.fgov.be/cgi_loi/change_lg.pl?lang uage $=$ nl\&la $=$ N\&cn $=2002052837 \&$ table_name $=$ wet. [dostęp: 08.08.2016].

${ }^{7}$ Por. J. Bonny, Verwachtingen van een bisschop, Antwerpen 2014, s. 7.

${ }^{8}$ Por. J. Orlandis, Gesiedenis van de Katholiek Kerk in de tweede helft van de 20set eeuw, Utrecht 2011, s. 105-106.

${ }^{9}$ Por. Dossier. Humane Vitae. Reacties op de Encycliek, Katholiek Archief Wyd. Amersfoort 1968, s. 11-17. 
Tekst encykliki spowodował przełom w relacji z Rzymem. Wielu biskupów, innych duchownych oraz wiernych świeckich nie odnalazło się w narzuconych odgórnie watykańskich normach i zaczęło praktykować wiarę według indywidualnych, prywatnych, relatywistycznie subiektywnych norm. Nauka moralna Kościoła znalazła się w ogniu krytyki. Warto zaznaczyć, że był to początek ery „sumienia subiektywnego" w której człowiek pragnie wówczas kontrolować życie, chce być jak Bóg. Wprowadzenie kontroli urodzeń poprzez społeczną zgodę na tabletki antykoncepcyjne oraz liberalne prawo aborcyjne było przygotowaniem pola dla eutanazji.

Kolejną sprawą, która istotnie wpłynęła na dehumanizację społeczeństwa, było swoiste zaślepienie rzeczami materialnymi. Lata sześćdziesiąte XX wieku jawią się jako początek rozwoju gospodarczego, zaczęło funkcjonować powszechnie powielane powiedzenie: The Sky is the Limit. Wygoda życia, negacja autorytetów oraz rozdzielenie seksualności od odpowiedzialności za życie doprowadziły do osłabienia relacji pomiędzy ludźmi. Człowiek, mając do dyspozycji możliwości techniczne oraz ekonomiczne, nie potrafi już cierpieć. Stąd też między innymi eutanazja jest traktowana jako ucieczka od cierpienia.

Utrata wiary w Boga prowadzi do egoizmu oraz utraty celu życia. Jeden z najbardziej katolickich krajów Europy w ciąguostatnich 50 lat stał się miejscem, gdzie odrzuca się życie i jego świętość. Człowiek uznał w Bogu agresora swojej wolności, dlatego próbuje żyć Si Deus non daretur $^{10}$.

\section{Historyczno-społeczne uwarunkowania przemian obyczajowych w Belgii}

Prawodawstwo belgijskie pod pretekstem progresywności, nowoczesności i otwartości bardzo mocno akcentuje ,indywidualność moralną”, prawa związków homoseksualnych, sztuczną regulację urodzeń, prawo do aborcji oraz eutanazji. Promuje się takie wartości, jak: szczęście i przyjemność oraz łatwe i dostatnie życie. Postawą, która łączy wyżej wymienione tendencje, jest pragnienie „wolności”, bardzo często rozumianej jako negacja norm moralnych. Analizując źródła wyżej wspomnianej tendencji, Marc Desmet SJ, wyróżnia pięć podstawowych czynników określających postawy mieszkańców Belgii: pragnienie wolności, liberalność belgijskiego katolicyzmu, obecność lóż masońskich, niezależność socjalno-ekonomiczną, a także zawiedzione nadzieje pokładane w Soborze Watykańskim II oraz rozczarowanie encykliką bł. Pawła VI Humanae vitae.

\footnotetext{
${ }^{10}$ Por. J. Ratzinger, Europa Benedykta w kryzysie kultur, Częstochowa 2005, s. 33-34.
} 
W prezentacji tych czynników warto odwołać się do historii oraz uwarunkowań społeczno-obyczajowych. Powstanie Królestwa Belgii w 1830 roku było wynikiem protokołu londyńskiego jako owocu antyholenderskiego powstania. Mały kraj, położony pomiędzy Francją a Niemcami, przez wieki toczył walkę o niezależność. Wolność jako spełnione marzenie, które urzeczywistniło się w posiadaniu własnego państwa, stała się przyczyną ,wyzwolonej filozofii”, w ramach której wolny człowiek ma problemy z przyjęciem autorytetów i praw nałożonych przez władzę zewnętrzną.

Kościół katolicki w Belgii nosi w sobie piętno napięcia pomiędzy liberalnymi ateistami a działaczami opcji katolickiej. Od początków istnienia kraju belgijscy liberałowie oraz katolicy wspólnie walczyli przeciwko dominacyjnej postawie króla Holendrów Willema I. Odzyskanie niepodległości było możliwe również dzięki Kościołowi, który pozostawał złączony ze strukturami świeckimi. Wynikiem tej zależności był silny wpływ Kościoła na zakres rozwiązań społecznych, przez co forsował własną praktykę pastoralną. Przykładem może być wprowadzenie przez niektóre diecezje bardzo szerokich uprawnień do „rozgrzeszania ogólnego" 11 . Wpływ Kościoła na życie społeczności był na tyle dominujący, że w końcu zaczęto ograniczać jego rolę i eliminować z udziału w debacie publicznej.

Rola masonerii, która głęboko wniknęła do życia politycznego w Belgii, polega na walce nie tyle z duchowością, ile na zwalczaniu Kościoła Rzymskokatolickiego. Jej rola koncentruje się na osłabianiu autorytetu Kościoła oraz wspieraniu ustaw i projektów, które są antykatolickie. Marc Desmet wskazuje, że $0,5 \%$ ludności Belgii należy do masonerii. Jest to najwyższy wskaźnik na świecie. Uchwalona w roku 2002 ustawa o eutanazji była możliwa dzięki ingerencji loży masońskiej ${ }^{12}$.

Ekonomiczny dobrobyt miał istotny wpływ na etyczny liberalizm, który wycisnął piętno na duchowości człowieka. Dobrobyt stał się stymulantem niezależności oraz wzrostu napięcia pomiędzy ogólnymi normami a indywidualnym postępowaniem. Doprowadziło to do zanikania praktyk sakramentalnych, jak również praktyk pobożności ludowej, pojawiły się także problemy z posłuszeństwem w Kościele.

${ }^{11}$ Wprowadzenie do ,Orde van Dienst voor de Boeteliturgie [Porzadek liturgii pokutnej], zatwierdzonej przez Konferencję Belgijskich Biskupów w Mechelen 25.02.1975. Brussel 1976, s. 27.

${ }^{12}$ Zauważa się, że politycy biorący udział w tworzeniu ustawy byli członkami loży masońskiej, jednym z głównych zwolenników ustawy jest pochodzenia polsko-żydowskiego Frederik Erdman. L. Hancké, SP.A onder de knoet van de loge van de vrijmetselarij, http://forum.politics.be/ showthread.php?t=40341 [dostęp: 15.11.2017]; https://nl.wikipedia.org/wiki/Fred_Erdman [dostęp: 15.11.2017]; F. Keuleneer, Euthanasie: wie stelt zich eigenlijk boven de wet?, https://www.demorgen. be/opinie/euthanasie-wie-stelt-zich-eigenlijk-boven-de-wet-ba39b966/ [dostęp: 15.11.2017]; M. Desmet, Euthanasie: waarom niet?, Tielt 2015, s. 250. 
Belgowie wiele oczekiwali od Soboru Watykańskiego II. Spodziewali się rozluźnienia dyscypliny Kościoła w stosunku do jego nauki o moralności oraz zniesienia celibatu duchownych. Encyklika bł. Pawła VI traktująca o istocie celibatu Sacerdotalis caelibatus (24.06.1967) wzbudziła rozczarowanie i stała się przedmiotem kontestacji. Wielu duchownych porzuciło swoje powołanie kapłańskie. Kolejnym przedmiotem kontestacji i niezadowolenia była encyklika Humanae vitae (25.07.1968), która nie znalazła w tym kraju zrozumienia i nie została przyjęta. Również instrukcja Kongregacji Nauki Wiary Donum vitae (22.02.1987) „O szacunku dla rodzącego się życia i o godności jego przekazywania" nie znalazła w Belgii wielu zwolenników.

\section{Analiza ustawodawstwa belgijskiego dopuszczającego eutanazję}

Wpływ na kształt prawodawstwa eutanatycznego w Belgii ma holenderska ustawa zatytułowana „Nadzór nad zakończeniem życia na żądanie i pomocą w samobójstwie" przyjęta przez Wyższą Izbę Stanów Generalnych 12 kwietnia 2001 roku, jak również zmiana kodeksu karnego oraz ustawy o traktowaniu zwłok i ich pochówku ${ }^{13}$. „Uchwalenie tej ustawy zmierzało do uporządkowania stanu prawnego w taki sposób, aby litera prawa odzwierciedlała prowadzoną już od dłuższego czasu rzeczywistą politykę karną wobec eutanazji. Tym samym znowelizowany został kodeks karny, uchylając karalność dokonanej przez lekarza eutanazji"14.

Ustawa o eutanazji w Holandii przewiduje sześć koniecznych warunków, które muszą być bezwzględnie i łącznie spełnione. Lekarz musi być pewny wolności decyzji pacjenta. Choroba jest nieuleczalna, powodując występowanie cierpień, które są trudne do zniesienia. Zadaniem lekarza jest udzielenie rzetelnej informacji na temat rokowań dotyczących przyszłości. Lekarz wykonujący zabieg musi skonsultować się z innym specjalistą, który powinien wydać pisemną opinię, wyrażając zgodę na planowany zabieg lub nie udzielając jej.

Kolejnym kontrowersyjnym punktem jest eutanazja osób nieletnich. Ustawa dzieli je na dwie kategorie: od 12. do 16. roku życia oraz od 16. do 18. roku życia. W pierwszym przypadku do legalnego przeprowadzenia eutanazji jest potrzebna zgoda obopólna (kumulowana) nieletniego pacjenta oraz jego prawnego opiekuna. Dziecko musi być w stanie dostatecznego rozeznania i mieć świadomość podejmowanego czynu. W drugim przypadku nie jest wymagana

\footnotetext{
${ }^{13}$ Por. G. Mazur, Etyczna ocena legalizacji eutanazji w Holandii, Kraków 2003, s. 39.

${ }^{14}$ Por. K. Śmigacz, Pojęcie i rodzaje eutanazji, s. 794, www.wspia.eu/file/20295/70-ŚMIGA CZ+KAROLINA.pdf [dostęp: 09.09.2016].
} 
zgoda prawnych opiekunów, lecz należy ich o decyzji poinformować ${ }^{15}$. Holandia stała się pionierem w Europie na drodze ku najbardziej ,humanitarnemu umieraniu z godnością". Trzeba stwierdzić, że znalazła naśladowców, którzy ją zdecydowanie wyprzedzili. Najbardziej liberalnym krajem w świecie pod względem eutanazji jest Belgia ${ }^{16}$.

W marcu 2001 roku belgijska komisja senacka rozpoczęła pracę nad projektem ustawy, która miała dotyczyć eutanazji. Oprócz tego projektu wniesiono jeszcze jeden, który odnosił się do prawa do opieki paliatywnej. „Przy takim poglądzie na sprawę ustaw eutanatycznych problematycznym staje się fakt, że podmiotem ustawy nie jest pacjent ani też jego stanowienie, lecz lekarz i jego bezpieczeństwo prawne" ${ }^{\prime 17}$.

\section{a. Belgijska ustawa o eutanazji z 2002 roku}

W Belgii eutanazja jest uregulowana mocą ustawy „O eutanazji” z 28 maja 2002 roku. W myśl art. $3 \S 1$ „Ustawy o eutanazji” (Euthansiewet) zabieg eutanazji mógł być wykonany na osobie pełnoletniej lub „samodzielnej osobie nieletniej" (een ontvoogde minderjarige) ${ }^{18}$, która jest świadoma w chwili dokonywania prośby o zabieg oraz spełnia odpowiednie kryteria medyczne.

Zgodnie z przepisami ustawy, pacjent proszący o eutanazję musi znajdować się w sytuacji medycznej nierokującej nadziei oraz uskarżać się na stałe i niedające się zaakceptować cierpienie fizyczne lub psychiczne, którego nie da się uśmierzyć i które jest wynikiem ciężkiego i nieuleczalnego schorzenia, przypadkowego lub „patologicznego”. Prośba musi być wolną, przemyślaną i wielokrotnie powtórzoną decyzją pacjenta, który jest świadomy stanu swojego zdrowia. Musi ją wyrazić na piśmie zaopatrzonym w datę i własnoręczny podpis. Może je przygotować wcześniej lub $\mathrm{w}$ dniu zabiegu ${ }^{19}$. Jeżeli pacjent jest sparaliżowany lub nie umie pisać, wspomniany dokument może być przygotowany i podpisany przez osobę wybraną przez chorego. Świadkiem sporządzenia tego dokumentu musi być lekarz.

15 Por. Szadkowska, Zabójstwo eutanatyczne - tendencje liberalizacyjne w Europie na przyktadzie Belgii, s. 229.

16 Por. J. Malarczyk, Eutanazja - rozwiazania prawne, http://www.dps.pl/radar/zdrowie/ eutanazja.php [dostęp: 09.09.2016].

${ }^{17}$ Por. K. Śmigacz, Pojęcie i rodzaje eutanazji, dz. cyt., s. 794.

${ }^{18}$ Prawo belgijskie wyjaśnia, że osoba nieletnia, która zawarła związek małżeński, uzyskuje status „osoby samodzielnej” (art. 476 „Het huwelijk van de minderjarige heeft van rechtswege zijn ontvoogding ten gevolge"), oraz mając ukończone 15 lat, drogą sądową może uzyskać status „samodzielności prawnej” (art. 477).

${ }^{19}$ Por. art. 3.§2, Euthansiewet [Prawo o eutanazji], http://www.ejustice.just.fgov.be/cgi_loi/ change_lg.pl?language $=\mathrm{nl} \& 1 \mathrm{a}=\mathrm{N} \& \mathrm{cn}=2002052837 \&$ table_name $=$ wet. [dostęp: 08.08.2016]. 
Prawodawca dokonuje rozróżnienia pomiędzy pacjentem terminalnym a nieterminalnym, którego data naturalnej śmierci jest niemożliwa do oszacowania (może jeszcze długo żyć). W obu przypadkach eutanazja jest dopuszczalna. Lekarz dokonujący eutanazji zawsze ma obowiązek zasięgnięcia rady drugiego lekarza. W przypadku choroby nieterminalnej lekarz ma obowiązek zasięgnięcia opinii trzeciego lekarza - specjalisty od choroby, na którą cierpi pacjent. W obu przypadkach opinie wydane przez lekarzy nie mają wagi zobowiązującej dla lekarza prowadzącego wykonującego eutanazję. Wykonanie zabiegu eutanazji na osobie nieterminalnej może się odbyć po upływie przynajmniej jednego miesiąca od złożenia prośby.

Ustawa o eutanazji, obok zwykłej prośby o eutanazję, przewiduje także Oświadczenie woli. Jest to prośba o dokonanie eutanazji w przypadku utraty możliwości podejmowania decyzji (utraty świadomości) ${ }^{20}$. Tego typu prośba musi być podpisana przez dwóch świadków, z których przynajmniej jeden nie ma żadnej zależności ekonomicznej z proszącym. Chory w każdej chwili może wycofać prośbę. Złożone oświadczenie zachowuje ważność przez pięć lat.

Zabieg eutanazji może być wykonany wyłącznie przez lekarza. Pielęgniarze i pielęgniarki ani nikt z członków rodziny nie mają prawa wykonywać tego zabiegu. Lekarz musi być pewny, że pacjent w chwili wyrażenia zgody na eutanazję, przy wypełnianiu oświadczenia woli, był „,zdolny do działania” oraz świadomy podejmowanej decyzji. Lekarz musi być również pewny, że stan zdrowia pacjenta jest ciężki i nie rokuje nadziei na wyzdrowienie, a chorobie towarzyszy niemożliwe do opanowania cierpienie psychiczne lub fizyczne.

Lekarz jest zobowiązany do zasięgnięcia opinii u innego lekarza, który zarówno w stosunku do proszącego o eutanazję pacjenta, jak i lekarza prowadzącego, pozostaje niezależny. Nie jest jednak wymagana jego zgoda ${ }^{21}$. Jeżeli lekarz przypuszcza, że naturalna śmierć jest trudna od przewidzenia, powinien zasięgnąć opinii drugiego lekarza. Ten drugi lekarz musi być psychiatrą lub specjalistą od choroby, na którą cierpi pacjent.

\section{b. Ustawa belgijska z roku 2014}

Nowelizacja ustawy o eutanazji z 13 lutego 2014 roku rozszerza możliwości dokonywania eutanazji o osoby nieletnie, które nie mają samodzielno-

${ }^{20}$ Por. art. 4. § 1. „De patiënt een handelingsbekwame meerderjarige, of een handelingsbekwame ontvoogde minderjarige, of nog een oordeelsbekwame minderjarige is en bewust is op het ogenblik van zijn verzoek".

${ }^{21}$ Por. Hln, Het is tijd om de euthanasiewet te herzien, http://www.hln.be/hln/nl/957/Binnen land/article/detail/2605176/2016/02/03/Vanackere-Het-is-tijd-om-de-euthanasie wet-te-herzien.dhtml [dostęp: 08.09.2009]. 
ści prawnej. Zapis prawny znajduje się w 78. artykule belgijskiej konstytucji. Ustawa została zbudowana na bazie ustawy z roku 2002, wprowadzając stosowne rozszerzenia, np. powierzając dzieciom mającym wystarczające rozeznanie decyzję o dokonaniu eutanazji.

Ustawa przewiduje, że eutanazję może popełnić pełnoletni pacjent, który jest poczytalny, świadomy swoich czynów lub świadomy swojego wyboru „samodzielny nieletni” lub mający możliwość podjęcia decyzji nieletni ${ }^{22}$. Zmiana ustawy z 28 maja 2002 roku miała na celu umożliwienie eutanazji nieletnim, bez żadnych ograniczeń wiekowych. Artykuł 3, §1 „Ustawy o eutanazji" ${ }^{23}$ wskazuje 12 podstawowych warunków zgody na eutanazję.

1. Nieletni ma pełną świadomość podejmowanej przez siebie decyzji oraz zna jej konsekwencje; nie ma znaczenia wiek dziecka.

2. Nieletni znajduje się w stanie nierokującej poprawy choroby, trwałego cierpienia fizycznego (psychiczne cierpienie nie jest brane pod uwagę, w przeciwieństwie do dorosłych).

3. Prośba musi być dobrowolna, przemyślna i wielokrotnie powtórzona, wykluczająca jakąkolwiek zewnętrzną presję.

4. Pacjent musi zostać poinformowany o swoim stanie zdrowia oraz o możliwościach terapii lub paliatywnej opieki.

5. Lekarz prowadzący musi się upewnić, że cierpienie fizyczne ma trwały charakter.

6. Lekarz prowadzący powinien zasięgnąć opinii u innego niezależnego lekarza.

7. Lekarz ma zasięgnąć opinii u dziecięcego lub młodzieżowego psychiatry lub psychologa, który stwierdzi zdolność samodzielnego podjęcia decyzji u pacjenta.

8. Lekarz prowadzący omawia sytuację z prawnymi opiekunami dziecka oraz upewnia się o ich zgodzie na wykonanie zabiegu.

9. Prośba o zabieg napisana przez dziecko i zgoda jego prawnych opiekunów musi być sporządzona na piśmie.

10. Prośba musi zostać omówiona przez ekipę opiekunów dziecka, jeżeli taka ekipa istnieje.

11. Prośba powinna zostać podana do informacji osobom najbliższym dziecku, o ile dziecko je wskaże.

22 Por. art. 3.§ 1 (Euthanasiewet).,,De patiënt een handelingsbekwame meerderjarige, of een handelingsbekwame ontvoogde minderjarige, of nog een oordeelsbekwame minderjarige is en bewust is op het ogenblik van zijn verzoek".

${ }^{23}$ Por. Prawo o Eutanazji znajduje się w art. 78 belgijskiej Konstytucji, http://www.ejustice. just.fgov.be/cgi_loi/change_lg.pl?language $=$ nl\&la $=$ N\&cn $=2002052837 \&$ table_name $=$ wet. [dostęp: 09.09.2016]. 
12. W przypadku pozytywnego rozstrzygnięcia sprawy jest udzielana pomoc psychologiczna osobom związanym z eutanazją dziecka ${ }^{24}$.

Prawodawca wykluczył ,nieuprawionych nieletnich” z możliwości przygotowania sobie eutanazji na przyszłość poprzez napisanie Oświadczenia woli (Wilsverklaring euthanasie). Odrzucił też możliwość dokonania eutanazji w związku z chorobą psychiczną.

Ustawa o eutanazji chroni dzieci przed ich zabójstwem bez ich zgody. Jednak przeprowadzone w północnej Belgii (Flandria) badania nad zmarłymi niemowlętami, które żyły mniej niż 1 rok, wskazują, że w okresie pomiędzy sierpniem 1999 a lipcem 2000 roku, aż 57\% zbadanych zgonów zostało dokonanych umyślnie ${ }^{25}$. Badający wskazują, że $69 \%$ tych decyzji zostało podjętych w celu terminacji lub skrócenia życia. Zdecydowana większość decyzji (60\%) była związana z niepodjęciem lub zaniechaniem stosownych działań medycznych. W 28\% przypadków zostały zastosowane środki przeciwbólowe w dawkach, które miały uboczny skutek skrócenia życia. Naukowcy twierdzą, iż $12 \%$ dzieci otrzymało specjalny środek, który spowodował śmierć ${ }^{26}$. Lekarze dokonujący terminacji życia dzieci powołują się na „sytuację nadzwyczajną", w której, jak tłumaczą, życie dziecka jest niemożliwe do uratowania, a dziecko bardzo cierpi. Zauważa się tutaj konflikt pomiędzy obowiązkiem ratowania życia a uśmierzaniem bólu i cierpienia ${ }^{27}$.

\section{Reakcje na wprowadzone ustawy eutanatyczne}

Wprowadzenie ustawy o eutanazji i dzieci wywołało bardzo wiele dyskusji. Świat zareagował na tę ustawę medialnym protestem ${ }^{28}$. Konferencja Epi-

${ }^{24}$ Por. L. Proot, Euthansie voor minderjarigen, http://www.levenshuis.be/leif/euthanasie-voorminderjarigen [dostęp: 08.08.2016].

25 Por. G. Pouset, L. Deliens, De levneseindeproblematiek bij minderjarigen, e: Een zijden draadje. Kinderen, jongen en beslissingen rond het levenseinde, red. G.C. Cornelis. Brussel 2010. s. 40.

${ }^{26}$ Por. S. De Rocker, Euthanasie bij minderjarigen. Masterproef van de opleiding: Master in de rechten, Gent 2014, s. 57 http://lib.ugent.be/fulltxt/RUG01/002/162/983/RUG01-002162983_ 2014_0001_AC.pdf [dostęp: 08.08.2016].

${ }^{27}$ S. Peeters, W. Distelmans, F. Bussche Uitbreiding euthanasiewet eindelijk in zicht?, http://www. demens.nu/nl/OpiniesEnNieuws/opiniestukken/opinies/Uitbreidingeuthanasieweteindelijkinzicht. html. „Uit een onderzoek van Veerle Provoost en collega's (Lancet 2005) betreffende 298 overlijdens van kinderen van minder dan één jaar in Vlaanderen van 1 augustus 1999 tot en met 31 juli 2000 bleek dat er ook letale medicatie toegediend werd. Bij de 143 overlijdens waarbij een medische beslissing rond het levenseinde genomen werd, gebeurde dit bij 17 kinderen“.

${ }^{28}$ Por. The Associated Press, Belgian lawmakers extend euthanasia to children, http://news. nationalpost.com/news/belgian-lawmakers-extend-euthanasia-to-children?utm_source $=$ dlvr. it\&utm_medium=twitter [dostęp: 08.09.2016]. 
skopatu Belgii wydała stosowny dokument, w którym zachęca do wybierania życia przez lekarzy oraz proszących o eutanazję. Biskupi przestrzegają, że eutanazja zagraża rozwojowi społeczeństwa ${ }^{29}$. Pojawiły się liczne publikacje, które często miały tytuł: Belgowie sa mordercami dzieci ${ }^{30}$. Warto zauważyć pewien absurd - dzieci, które mają ograniczone prawa w sprawach życia społecznego i kwestiach materialnych, mogą decydować o życiu i śmierci. Poprzez eutanazję społeczeństwo dąży do wykluczenia osób najsłabszych - tych, które potrzebują opieki oraz mogą na nią liczyć. Bruno Waterfield, brytyjski korespondent $\mathrm{w}$ Brukseli pracujący dla brytyjskiego czasopisma „The Telegraph”, opisał tę kwestię jako: „rodzący niepokój trend” i uważa, że Belgia jest obojętna na wprowadzenie nowego prawa. „Społeczeństwo zakazuje kary śmierci, ale lekarzom pozwala zabijać ludzi" ${ }^{31}$. To, co małe, ocala świat zesztywniały w swojej wyimaginowanej wielkości, przywracając mu nadzieję, lecz człowiek dorosły nie chce dać mu szansy ${ }^{32}$.

Jeden z ukraińskich dziennikarzy zauważył sprzeczną sytuację - kraj o wysoko rozwiniętej medycynie i opiece paliatywnej potrzebuje takiego „dziwnego" prawa. Francuscy dziennikarze byli zaniepokojeni brakiem reakcji belgijskiego społeczeństwa. Brytyjczycy pytali, jak dziecko może być w pełni odpowiedzialne za zgodę na własną śmierć. Bardzo jasne było stanowisko amerykańskich mass mediów. Na stronie „Fox News”, Thomas Cal napisał, że brak respektu wobec wartości, jaką jest życie, może doprowadzić do zagłady społeczeństwa ${ }^{33}$. Jednak w Belgii nie było licznych protestów przeciwko prawu legalizującemu eutanazję.

Ustawa belgijska narusza podstawowe zasady płynące z prawa naturalnego i Bożego. Państwo za pomocą narzędzi, jakie daje demokracja, niszczy tego, który jest podmiotem demokracji. Warto zauważyć, że w tej sytuacji zmienia się celowość medycyny. To, co było bardzo ważnym elementem przysięgi Hi-

${ }^{29}$ Por. Euthanasie en het sociale weefsel, http://www.pastoralezorg.be/cms2/uploads/image/ elisabeth/visietekst\%20bisschoppen.pdf [dostęp: 07.08.2016].

${ }^{30}$ Por. W. Bouchrika, Wereld reageert op euthanasiewet voor kinderen: Belgen zijn kindermoordenaars, http://www.knack.be/nieuws/belgie/wereld-reageert-op-euthanasiewet-voor-kinderenbelgen-zijn-kindermoordenaars/article-normal-128873.html [dostęp: 08.08.2016].

31 Por. B. Waterfield, Euthanasia and indifference, https://twitter.com/brunobrussels/status/ 433933525104877568 [dostęp: 09.09.2016].

32 Por. C. Rise, Dziecko i chore społeczeństwo, Poznań 2010, s. 85.

${ }^{33}$ Por. T. Cal, Euthanasia in Belgium for terminally ill kids? The culture of death continues its grim march, http://www.foxnews.com/opinion/2013/12/17/euthanasia-in-belgium-for-terminallyill-kids-culture-death-continues-its-grim.html [dostęp: 15.11.2017]. „Absent a standard for life's value, the state could get to decide based on its interests. In the extreme we get Stalin's Russia with its forced famine, gulags and executions; Mao's China and the cultural revolution; Germany's Third Reich and its «Final Solution» and slavery in America with its Three-Fifths Compromise, which, for representation purposes, determined that slaves would be counted not as full human beings, but as «three-fifths of all other Persons»". 
pokratesa: ,zakaz podawania śmiercionośnej trucizny”, zostało wyparte przez nowoczesną formę służby śmierci. Katolicki kraj w swojej postępowości niszczy fundamenty, w imię humanizmu staje się ahumanistyczny. Powszechnie proklamowana wolność jest w rzeczywistości siatką niewolniczych struktur.

Schizofreniczną postawę panującą w tym społeczeństwie obrazują dwie sytuacje:

a. Dyrekcja katolickiego domu opieki „Huize Sint-Augustinus” w Diest została uznana za winną i ukarana przez sąd w Leuwen karą 6 tysięcy euro za odmówienie w roku 2011 wykonania eutanazji na 74-letniej kobiecie ${ }^{34}$.

b. Marc Desmet, jezuita, lekarz pracujący w szpitalu, wielokrotnie zapraszany z odczytami w sprawie eutanazji, jest jej cichym promotorem. W swojej książce Euthanasie: waarom niet? wyznaje: „Wierzę, że eutanazja nie jest «zabójstwem», ale łagodną i radykalną formą zakończenia życia"35. Pracując jako lekarz, zajmuje się także przygotowywaniem ludzi do eutanazji. Swoje odczyty dla studentów zaczyna zwykle stwierdzeniem: „Jeżeli ktoś pyta mnie: «Co myślisz o eutanazji?», odpowiadam: „Nie wiem..., ale wierzę, że inne rzeczy są o wiele ważniejsze" ${ }^{\prime 36}$. W swoich książkach i artykułach bardzo pozytywnie wypowiada się o „dobrej śmierci” jako wielkim dobrodziejstwie. Bardzo zasmucające jest to, że duchowny nie ma krytycznego stanowiska w kwestii eutanazji. W swojej książce Euthanasie: waarom niet? stwierdza: „Teraz mamy eutanazję, a ja «współpracuję». Jesteśmy w czołówce na świecie, wyprzedziliśmy nawet Holandię"37.

Mimo apeli o obudzenie sumienia mentalność eutanatyczna w Belgii szerzy się w zastraszającym tempie. Jest to owoc postępującej sekularyzacji oraz utraty korzeni chrześcijańskiej duchowości. Wzrost dobrobytu przyczynia się do zawężenia perspektywy pragnień do dóbr konsumpcyjnych i negowania sfery religijności. Bardzo niepokojącym zjawiskiem jest dynamicznie rosnąca w Belgii liczba wykonywanych eutanazji. Socjologowie podają, że w 2015 roku odnotowano 2021 zgonów w wyniku eutanazji ${ }^{38}$. Większość zabiegów, 80\%, jest wykonywana we Flandrii (północnej, najbogatszej części Bel-

${ }^{34}$ Por. P. Beukers, België: Katholiek woonzorgcentrum veroordeeld voor weigeren euthanasie, http://www.katholieknieuwsblad.nl/nieuws/belgie-katholiek-woonzorgcentrum-veroordeeld-voorweigeren-euthanasie [dostęp: 08.09.2016].

${ }^{35}$ M. Desmet, Euthanasie: waarom niet?, dz. cyt., s. 34.

${ }^{36}$ Tamże, s. 31.

${ }^{37}$ Tamże, s. 21.

${ }^{38}$ Por. Belga, Voor het eerst meer dan 2.000 aangiftes van euthanasie, http://www.hln.be/hln/ nl/33/Fit-Gezond/article/detail/2598312/2016/01/27/Voor-het-eerst-meer-dan-2-000-aangiftes-vaneuthanasie.dhtml. [dostęp: 08.09.2016]. 
gii) ${ }^{39}$. Liczba eutanazji w ciągu 6 lat podwoiła się. W 2007 roku 2\% zgonów zaistniało dzięki eutanazji, a w 2013: 4,6\%. Warto zauważyć, że w Holandii liczba eutanazji utrzymuje się na stałym poziomie $2,8 \%$.

W 2014 roku do belgijskich urzędów wpłynęło 24360 Wilsverklaringen (Oświadczeń woli). Są to przedwczesne prośby o dokonanie eutanazji w przewidywanym przypadku braku świadomości. Z danych Federale Overheidsdienst Volksgezondheid (Federalnej Agencji Służby Zdrowia) wynika, że jest to rekordowa liczba, o 3946 więcej niż rok wcześniej. Warto przypomnieć, że w oświadczeniu woli pacjent prosi o wykonanie eutanazji w przyszłości, gdy znajdzie się w stanie nieświadomości.

Eutanazja praktykowana Belgii od 2002 roku stanowi zwierciadło duchowej pustki. Człowiek przestał rozumieć transcendentalny wymiar swojego istnienia. Nie traktuje już życia jako wspaniałego daru, ale jako swoją własność, samego siebie stawiając na miejscu Boga. Cierpienie, stanowiące istotny element życia, uważa za bezużyteczne, a życie, które jest nim zabarwione, postrzega jako bezsensowne. Rozwój mentalności eutanatycznej niesie spustoszenie i strach, gdyż ludzie chorzy i starsi idący do szpitala zaczynają się obawiać o swoje bezpieczeństwo.

Tomasz Terlikowski napisał, że w Belgii w roku 2015 lekarze „zabili” ponad dwa tysiące osób. Terroryści - „tylko” nieco ponad 30. „I kto tu jest prawdziwym zabójcą?" - pyta katolicki publicysta ${ }^{40}$. Dramatyczny staje się los człowieka, który przez społeczeństwo został uprzedmiotowiony, stając się jednym z elementów ekonomii. Zdarzają się przypadki, że dzieci dowiadują się o dokonaniu eutanazji na swoich schorowanych rodzicach już po fakcie ${ }^{41}$. Lekarze, którzy są powołani do ratowania życia, często niosą śmierć. Rozszerza się proceder zabijania dzieci z poważnymi chorobami, tuż po ich urodzeniu. Ludzie boją się korzystać z usług szpitali. Twierdzi się, że w Belgii lekarz 1000 razy w ciągu roku decyduje o zadaniu śmierci. Badania wskazują, że na 60 przypadków śmierci jeden został przyśpieszony przez lekarza, często bez poinformowania i zgody najbliższej rodziny 42 .

Najbardziej dramatycznym faktem jest to, że dzieci zostały obdarzone możliwością podjęcia decyzji o własnej śmierci. Biskupi belgijscy w oświadczeniu wydanym po nowelizacji ustawy o eutanazji umożliwiającej zabijanie

39 VTM,Veel (wilsverklaringen) euthanasie in België, http://www.beforeyougo.be/nl/blog/ detail/News/2015/veel-wilsverklaringen-euthanasie-in-belgie [dostęp: 09.08.2016].

${ }^{40}$ Por. T. Terlikowski: Wpis na Twitter $\mathrm{z}$ dnia 22.03.2016. https://twitter.com/tterlikowski/ status/712264447155429376 [dostęp: 08.09.2016].

${ }^{41}$ Por. J. Jałowiczor, Regulamin zabijania, http://gosc.p1/doc/3028986.Regulamin-zabijania/2 [dostęp: 08.09.2016].

${ }^{42}$ Por. Het Laatste Nieuws, 1000 keer per jaar beslist arts over dood, http://www.hln.be/hln/ nl/33/Fit-Gezond/article/detail/2358991/2015/06/15/1-000-keer-per-jaar-beslist-arts-over-dood. dhtml [dostęp: 15.07.2016]. 
nieletnich wyrazili swój protest i zadali pytanie o przyszłość. Istnieje niebezpieczeństwo, że aktualne prawo będzie przedpolem do kolejnych rozszerzeń, które będą dążyły do usunięcia ze społeczeństwa poprzez „dobrą śmierć” osób niepełnosprawnych, cierpiących na demencję, chorych umysłowo oraz zmęczonych życiem ${ }^{43}$. Warto zatem zadać sobie pytanie o bezpieczeństwo tych, którzy są najbardziej niewinni, którzy liczą na pomoc. Czy osoby chore i niewinne dzieci mogą liczyć na gwarancję bezpieczeństwa w dzisiejszej Belgii? Analiza przyczyn decyzji o skierowaniu prośby o eutanazję i sposobu uchwalania prawa jasno wskazuje, że tylko powrót do wartości ewangelicznych, wskazujących na niezbywalną wartość ludzkiego życia, może dać ludziom poczucie nadziei i bezpieczeństwa.

\title{
PRACTICE OF EUTHANASIA IN BELGIUM AS FRUIT OF SOCIAL AND CIVIL TRANSFORMATIONS
}

\author{
Summary
}

The Belgian act legalising euthanasia was passed on 28th May 2002 and was amended on 28th February 2014. The new law has made euthanasia accessible to juveniles without age restrictions and is an innovation which violates basic Christian values. But opening to killing of innocent people might be the beginning of society's self-destruction. It is a dangerous thought that juveniles, who are limited in their rights because of their immaturity, are allowed to choose destruction of the greatest gift - life itself. This is fruit of social and civil changes and specially consequence of process of secularization.

A rapid increase of euthanasia applications of patients with certain conditions and who fear losing consciousness, raises questions concerning the future and safety. There is also a question of trust in doctors, who under Belgian law may bring death in the name of providing healthcare. A doctor may only proceed with the performance of euthanasia in accordance with certain procedures, but many times procedures are violated and lives are endangered.

Słowa kluczowe: eutanazja; małoletni pacjenci; Belgia; oświadczenie woli; teologia moralna

Keywords: euthanasia; juvenile patients; Belgium; living will; moral theology

43 Por. Belga, Belgische bisschoppen "zeer ontgoocheld" over uitbreiding euthanasiewet [Oświadczenie Biskupów Belgii z dnia 14.02.2014]. http://www.hln.be/hln/nl/957/Binnenland/ article/detail/1793263/2014/02/13/Belgische-bisschoppen-zeer-ontgoocheld-over-uitbreidingeuthanasiewet.dhtml [dostęp: 10.09.2016]. 


\section{BIBLIOGRAFIA}

Bonny J., Verwachtingen van een bisschop, Antwerpen: Wyd. Halewijn 2014.

Desmet M., Euthanasie: waarom niet?, Tielt: Wyd. Lannoo 2015.

Distelmans W., Een waardig levenseinde, w: Een zijden draadje. Kinderen, jongeren en beslissingen rond het levenseinde, Brussel: Wyd. Vubpress 2010, s. 18-29.

Dossier. Humane Vitae. Reacties op de Encycliek, Katholiek Archief Wyd. Amersfoort 1968.

Israel L., Eutanazja czy życie aż do końca, Kraków: Wyd. WAM 2003.

Kongregacja Nauki i Wiary, Deklaracja o eutanazji Iura et bona (05.05.1980), w: W trosce o życie, Tarnów: Wyd. Biblos 1998, s. 333-339.

Kongregacja. Nauki Wiary, Instrukcja o szacunku dla rodzącego się życia ludzkiego i o godności jego przekazywania Donum vitae (22 02. 1987), w: W trosce o życie, Tarnów: Wyd. Biblos 1998, s. 360-385.

Mazur G., Etyczna ocena legalizacji eutanazji w Holandii, Kraków: Wyd. PAT 2003.

Orde van Dienst voor de Boeteliturgie, Brussel: Wyd. I.C.I.Z 1976. [Porzadek liturgii pokutnej]

Orlandis J., Geschiedenis van de Katholiek Kerk in de tweede helft van de 20set eeuw, Utrecht: Wyd. Atrium 2011.

Pouset G., Deliens L., De levneseindeproblematiek bij minderjarigen, w: Een zijden draadje. Kinderen, jongen en beslissingen rond het levenseinde, red. G.C. Cornelis, Brussel: Wyd. Vubpres 2010, s. 34-51.

Ratzinger J., Europa Benedykta w kryzysie kultur, Częstochowa: Wyd. Święty Paweł 2005.

Rise C., Dziecko i chore społeczeństwo, Poznań: Wyd. W drodze 2010.

\section{Strony www:}

Belga, Belgische bisschoppen "zeer ontgoocheld" over uitbreiding euthanasiewet, [Oświadczenie Biskupów Belgii z dnia 14.02.2014], http:/www.hln.be/hln/nl/957/Binnenland/article/ detail/1793263/2014/02/13/Belgische-bisschoppen-zeer-ontgoocheld-over-uitbreidingeuthanasiewet.dhtml [dostęp: 10.09.2016].

Belga, Voor het eerst meer dan 2.000 aangiftes van euthanasie, http://www.hln.be/hln/nl/33/Fit-Gezond/article/detail/2598312/2016/01/27/Voor-het-eerst-meer-dan-2-000-aangiftes-van-euthanasie.dhtml [dostęp: 08.09.2016].

Bouchrika W., Wereld reageert op euthanasiewet voor kinderen: Belgen zijn kindermoordenaars, http://www.knack.be/nieuws/belgie/wereld-reageert-op-euthanasiewet-voor-kinderen-belgenzijn-kindermoordenaars/article-normal-128873.html [dostęp: 08.08.2016].

Cal Th., Euthanasia in Belgium for terminally ill kids? The culture of death continues its grim march, http://www.foxnews.com/opinion/2013/12/17/euthanasia-in-belgium-for-terminally-ill-kidsculture-death-continues-its-grim.html [dostęp: 15.11.2017].

Chambaere K., Vander Stichele R., Mortier F., Cohen J., Deliens L., Recent Trends in Euthanasia and Other End-of-Life Practices in Belgium, "The New England Journal of Medicine" 2015. 372:1179-11, http://www.nejm.org/doi/full/10.1056/NEJMc1414527\#t=article [dostęp: 08.08.2016].

De Rocker S., Euthanasie bij minderjarigen. Masterproef van de opleiding: Master in de rechten, Gent 2014, s. 57, http://lib.ugent.be/fulltxt/RUG01/002/162/983/RUG01-002162983_2014_0001_AC. pdf. [dostęp: 08.08.2016].

Hancké L., SP.A onder de knoet van de loge van de vrijmetselarij,

http://forum.politics.be/showthread.php?t=40341 [dostęp: 15.11.2017].

https://nl.wikipedia.org/wiki/Fred_Erdman. [dostęp: 15.11.2017].

Keuleneer F., Euthanasie: wie stelt zich eigenlijk boven de wet?, https://www.demorgen.be/opinie/ euthanasie-wie-stelt-zich-eigenlijk-boven-de-wet-ba39b966/ [dostęp: 15.11.2017]. 
Peeters S., Distelmans W., Bussche F., Uitbreiding euthanasiewet eindelijk in zicht?, http://www.de mens.nu/nl/OpiniesEnNieuws/opiniestukken/opinies/Uitbreidingeuthanasieweteindelijkinzicht. html [dostęp: 08.09.2016].

Proot L., Euthansie voor minderjarigen, http://www.levenshuis.be/leif/euthanasie-voor-minderjarigen [dostęp: 08.08.2016].

Szadkowska M., Zabójstwo eutanatyczne -tendencje liberalizacyjne w Europie na przyktadzie Belgii, „Studia Iuridica Toruniensia”, https://repozytorium.umk.pl/bitstream/handle/item/2023/ SIT.2013.024,Szadkowska.pdf?sequence=1. s. 8 [dostęp: 08.08.2016].

Marcin Derdziuk OFMCap, ur. w 1980 w Zamościu, w zakonie kapucynów Prowincji Warszawskiej od 1999 roku, od 2009 roku pracuje duszpastersko w Antwerpii w Belgii, doktorant Instytutu Teologii Moralnej KUL 